Volume 8 , Issue 2

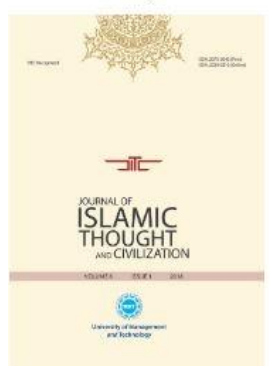

Journal of Islamic Thought and Civilization (JITC)

Volume 8, Issue 2, Fall 2018

ISSN: 2075-0943, eISSN: 2520-0313

Journal DOI: https://doi.org/10.32350/jitc

Issue DOI: https://doi.org/10.32350/jitc.82

Homepage: https://www.umt.edu.pk/jitc/home.aspx

Journal QR Code:
Article:

Author(s):

Online

Published:

Article DOI:

Article QR

Code:

Copyright Information
Terrorism and Racial Profiling-Islamophobia in International Press

Khadijha Tariq

Mian Abdul Hanan

Fall 2018

https://doi.org/10.32350/jitc.82.08

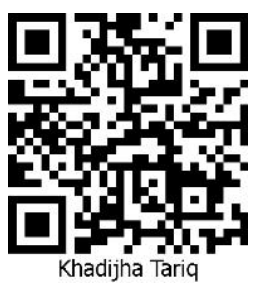

Tariq, Khadijha, and Mian Abdul Hanan. "Terrorism and racial profiling-Islamphobia in International press."

Journal of Islamic Thought and Civilization 8, no. 2 (2018): 127-144.

\section{Crossref}

This article is open access and is distributed under the terms of Creative Commons Attribution - Share Alike 4.0 International License

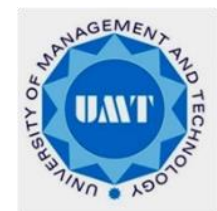

A publication of the

Department of Islamic Thought and Civilization

School of Social Science and Humanities

University of Management and Technology

Lahore, Pakistan.
Indexing Partners

INDEX

ISLAMICUS

Crossref

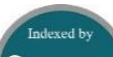

Scopus

(5) WorldCat

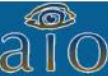

GENERALIMPACTFACTOR

INDEX COPERNICUS
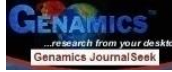

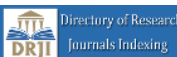

$\mathrm{R} \partial \mathrm{AD}=$

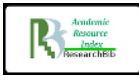

$\int \sum_{12}$

For more, please

click here 


\title{
Terrorism and Racial Profiling-Islamophobia in International Press
}

\author{
Khadijha Tariq ${ }^{*}$ \\ Content Writer-Academia Magazine Office of Communications and Media \\ University of Management and Technology, Lahore \\ Mian Abdul Hanan \\ Department of Media and Communication \\ University of Management and Technology, Lahore
}

\begin{abstract}
This paper provides an insight into the methods that were adopted for the racial profiling of Muslims after 9/11; as suspected perpetrators of terrorism globally. This paper examines the history and origin of the word islamophobia, some phenomena that is effecting the stature and identity of Muslims worldwide. The purpose of this study is to analyze the tone, structure and themes presented by the print media prior to a terrorist activity, with the aim of finding out whether any inherent bias was visible or not. This paper explores the role of the international press in linking Islam and terrorism and highlights the effects of subtle print messages that can lead to racial profiling of Muslims and generation of Islamophobia. The data for this research is collected from the editorials in six leading international newspapers from 2014 to 2017, randomly creating strata of 10 major international terrorist activities. The researcher has analyzed editorials for a period of one month after the incident. Data is analyzed through event methodology and content analysis and after statistical interpretation provides the results and findings of the researcher.
\end{abstract}

Keywords: Terrorism, Islam, Islamophobia, Print media, Racial profiling

\section{Introduction}

The twenty-first century can be regarded as the age of terrorism, a propaganda that is based upon the doctrine of spreading fear and terror amidst the masses. The role of media in shaping the opinions, ideas, point of views and attitudes of the audiences cannot be challenged. Media presents them information and facts about what is happening around the world and how these events affect them, formulating their perspectives. However, no terrorist activity can have pervasive influence until it is given maximum exposure by the media. Messages are distributed through a systematic projection to places that are virtually far away from the country or region, where the terrorist activity has taken place; with the aim of proliferating an innate perceptible threat or fear of terrorism at large.

The international press uses various metaphors and frames such as 'Islamic Terrorism,' 'Muslim terrorist' and radical Muslim' to propagate Islamophobia; maligning the image of the entire Muslim community. These conscious efforts on the part of media leads to increasing need for surveillance and security, where different methods of racial

${ }^{*}$ Correspondence concerning this article should be addressed to Khadijha Tariq, Content Writer, Academia Magazine, Office of Communication and Media (OCM), UMT, khadijhatariq@gmail.com

JOURNAL OF BLLAMIC THOUGHT AND CIVLIZATION

Volame 8 lsoue 2 2018 
profiling are used by the police against Muslims. These leading international press players have repeatedly probed their respective governments to take necessary actions against the Muslim community by projecting them as 'Other Muslims,' 'Violent Muslims,' 'Radicals,' 'Fundamentalists,' 'Islamic terrorism' etc.

Such biased imagery building of Muslims has led to an automated conditional cognition of the western readers, where they consider every practising Muslim the root cause of terrorism and have developed a psychological fear towards them called 'Islamophobia.' This study aims to explore the role of the international press in the framing and representation of Muslims in the context of terrorism. This paper provides an insight into how and why terrorism is associated with Islam, the origin of the concept of Islamophobia and analyzes the dimensions of racial or religious profiling. Furthermore, this paper highlights the role of the international press in the proliferation of Islamophobia and religious or racial profiling of Muslims globally.

\section{Background}

The global menace of terrorism is escalating and poses serious threats to national and international security. The global terrorism index (2016) ${ }^{1}$ highlights that countries including; Afghanistan, Iraq, Nigeria, Pakistan and Syria have seen the highest impact of terrorism in 2015; accounting almost Seventy-Two percent deaths from terrorism alone. ISIL has been considered as the deadliest terrorist organization in 2015 carrying out 252 terrorist attacks in multiple cities, causing 6,141 deaths in just a year. Root causes of terrorism are multi-dimensional and do not involve around psychological, political and socio-economic conditions only but it also includes situational and circumstantial factors that are global or indigenous, specific or general, dynamic or static, activating or enabling which fundamentally overlap one another. ${ }^{2}$

Media and terrorism are in a "reciprocal relationship" which further facilitates an upward spiral of violence where terrorists compete with each other for media attention. Media coverage works as a vehicle of communication for terrorists and supports them to spread fear and suspicion, provides a legitimacy to their terror acts and aids them in reaching a wider target audience, creating an asymmetry between the terrorist and the entities they are fighting against. ${ }^{3}$ The traditional media has now been replaced by the internet which is much quicker and effective method of disseminating messages to a wider audience ${ }^{4}$

After 9/11 Islamic terrorism was repeatedly used by the media as a cultural stereotype and frames such as violence, fanaticism, extremism and terrorism were used to portray Muslims. Religious terrorists interpret and justify their acts in the light of Qur'ānic injunctions and Hadīth, however, their acts are solely based upon their own

\footnotetext{
${ }^{1}$ Global Terrorism Index (2016), http://economicsandpeace.org/wpcontent/uploads/2016/11/Global-Terrorism-Index-2016.2.pdf

Joshua Sinai, Root Causes of Terrorism: Myths, Reality and Ways Forward (London: Routledge, 2005), 215-222.

3 Arda Bilgen, "Terrorism and the Media: A Dangerous Symbiosis," http://www.eir.info/2012/07/22/terrorism-and-the-media-a-dangerous-symbiosis/ accessed on 16.4.2018

${ }^{4}$ Brigitte Nacos, "Terrorism/Counterterrorism and Media in the Age of Global Communication," Lecture, United Nations University Global Seminar, UN, August 5, 2006. http://archive.unu.edu/gs/files/2006/shimane/Nacos_text_en.pdf
}

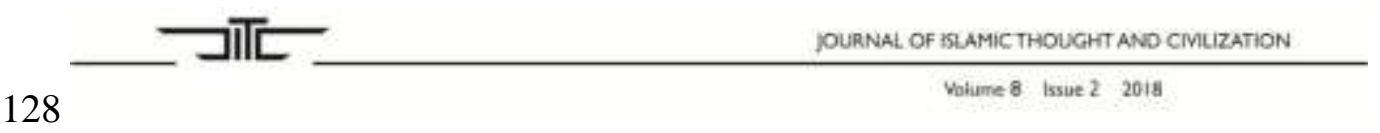


malicious and terrorizing goals. Islam denounces every kind of violence and studying the concept of Jihäd reveals that it is a fight or effort rather than just a holy war against infidels. ${ }^{5}$ Traditional Muslim jurists condemn the killing of innocent defenceless people and label all such perpetrators as foulest criminals. ${ }^{6}$

Terrorism has taken a new turn in the Twenty-first century where its upsurge has become an enigma for researchers and scholars. Diverse reasons have been presented in the context of terrorism, however blaming religion as an ember that ignites terrorism; is the most discussed and debatable one. The verdict on this discussion has been divided where most of the scholars believe that religion itself has an inherent predisposition towards violence. Some scholars believe that religion is just an ideological construction and there is no religion as such. Western scholars believe that religion leads to violence and terrorism because it is illogical, absolutist and conflict-ridden. ${ }^{7}$ In concurrent times, the religious imperative is a defining characteristic of modern day terrorism. ${ }^{8}$

The word Islamophobia is not a mere reflection of the actions, practices and discrimination directed towards Muslims but is an amalgamation of the meanings that are disseminated through various channels. These meaning than shape the course of actions, practices and discriminations against Muslims. The process of Islamophobia proceeds in three steps. The first step is 'stereotypification,' the process in which an evaluative 'hierarchy' is constructed so that meanings and knowledge related to individuals can be mainstreamed within the society's cognition. The second step is 'representation,' identifiers that denotes how symbols embody underlying meanings (hijäb as a symbol of fundamentalism). The third step is 'semiology,' the mechanism of building identifiers; to highlight the underlying meanings within symbols so that they can become part of society's social fabric (identification of hijābi with perpetrators of terrorism. ${ }^{9}$ AntiIslamic and anti-Muslim discourses such as Islamophobia can be understood as 'political spectacles.' These dramas invoke as well reinforce psychological distancing syndromes within viewers. Responses of fear and anxiety are generated towards issues that are dramatized by the writer; for gaining political objectives and formulation of public perceptions. ${ }^{10}$

Racial profiling is the unfair or biased targeting of minorities by the police; based solely upon the belief that these people have more chances of getting involved or having an inclination towards crime. ${ }^{11}$ Prior to $9 / 11$ debates on racial profiling were mostly related to blacks and Latinos and their involvement in criminal activities and drug abuse.

\footnotetext{
5 Juhaya Praja, "Islam, Globalization and Counter Terrorism," Resource material series/United Nations Asia and Far East Institute for the Prevention of Crime and the Treatment of Offenders, Vol. 71, 32-39.

${ }^{6}$ Abou Khalid El-Fadl, "Terrorism is at Odds with Islamic Tradition," The Los Angeles Times, September 22, 2001.

${ }^{7}$ William Cavanaugh, The Myth of Religious Violence: Secular Ideology and the Roots of Modern Conflict (New York: Oxford University Press, 2009).

${ }_{9}^{8}$ Hoffman Bruce, Inside Terrorism (New York: Columbia University Press, 2006).

${ }^{9}$ Christofer Allen, Islamophobia (Surrey: Ashgate Publishing Group, 2010).

${ }^{10}$ Murray Edelman, Constructing the Political Spectacle (Chicago: University of Chicago Press, 1988).

${ }^{11}$ Michael Buerger, "Racial Profiling," In J. M. Miller, 21st Century Criminology: A Reference Handbook (Thousand Oaks, 2009), 741-749.
} 
However, after 9/11 this debate took a turning point and legitimized the use of racial or religious profiling against Muslims and Arabs in the context of terrorism. Thousands of Muslims and Arabs were questioned and detained on mere suspicions ${ }^{12}$ and intelligence agencies monitored mosques and threatened young men to serve as informers. ${ }^{13}$ Diverse literature is available on the ethnicities and races that are prone to be profiled however less content are available on the perception of audiences about racial profiling. A few available types of research on the attitudes of people toward racial and religious profiling reveal that the public supports profiling for curbing terrorism only. ${ }^{14}$ Saad (2006) ${ }^{15}$ in his research quoted Gallup survey, 2006 stating that almost Forty-One per cent people favoured intensive searching of Muslims before boarding planes, as a measure to prevent any terror act in America.

\section{Methods}

The researcher will be using content analysis to determine and examine the role of international press coverage in relation to terrorist incidents. Hsieh and Shannon ${ }^{16}$ defined qualitative content analysis as "a research method for the subjective interpretation of the content of text data through the systematic classification process of coding and identifying themes or patterns. 17,

Furthermore, the researcher will find out the prominent themes and frames within the editorials that may or may not lead to the racial/religious profiling of Muslims and the proliferation of Islamophobia globally. Media framing theory states that framing comprises of the methods that are employed by journalists for organizing and presenting information to the audiences. News frames serve various purposes such as they organize information in a way that a story can be built upon them, exclude certain aspects of a story while including others and proposes perspectives that form the basis of their evaluations and judgments. 18

A sample of ten major international terrorist events has been randomly selected by the researcher from 2014 to 2017 . The researcher will be analyzing the editorials published in six leading international dailies that are available online; for a period of 30 days starting from the day and date of the specific terrorist event. The data would be entered in SPSS Software 10 and One-way ANOVA will be applied to find out whether any significant association is present within the news coverage of leading dailies and how they have portrayed Muslims/Islam in the context of Terrorism. Simple cross tabulation will be used to find out the frequency of Islamophobic frames within editorials,

${ }^{12}$ David Cole and Enemy Aliens. Double Standards and Constitutional Freedoms in the War on Terrorism (New York: New Press, 2005).

13 Ibid.

${ }^{14}$ Deven Johnson, et al., "Attitudes towards the Use of Racial/Ethnic Profiling to

Prevent Crime and Terrorism," Criminal Justice Policy Review 22 (4), (2011): 422-447.

${ }^{15}$ Lydia Saad, "Anti-Muslim Sentiments Fairly Commonplace. Four in ten Americans Admit Feeling Prejudice against Muslims," Gallup Poll News Service, 2006.

${ }^{16}$ Hsieh Hsiu-Fang and Shannon Sarah. E, Three Approaches to Qualitative Content Analysis (Qualitative Health Research: 2005), 1277-1288.

${ }^{17}$ Ibid., 1278.

${ }^{18}$ Todd Gitlin, The Whole World is Watching Mass Media in the Making and unmaking of the New Left (Chicago: University of Chicago Press, 2003).

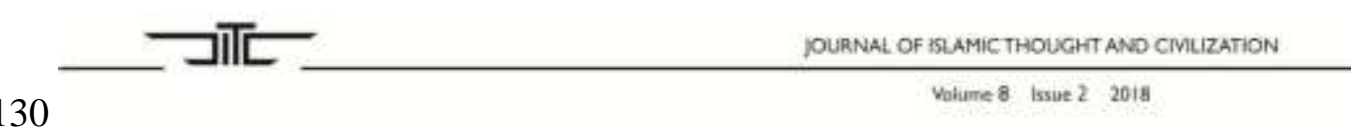


disparities in the coverage of terrorist events within newspapers and the frequency of profiling or mentioning of Muslim ethnicities within editorials.

This study focuses only the newspapers that were available online. The focus of the researcher was on the recent and major terrorist incidents from 2014-2017, choosing two incidents with non-Muslim terrorist involvement and eight incidents with Muslim terrorist involvement. The researcher focuses on only one dimension of racial profiling i.e. religion based racial profiling of Muslims.

\subsection{Coding Categories}

A coding sheet has been formulated with the following categories to find out the role of the international press in relation to Islamophobia and racial/religious profiling of Muslim:

- Editorial title

- Date and Month of publication

- Name of newspaper

1. Times of India (TOI)

2. The Express Tribune

3. The Guardian

4. Daily News

5. Toronto Sun

6. The National

- Name of event

1. APS Peshawar 2014 (Pakistan)

2. Charlie Hebdo 2015 (France)

3. Borno state bombing 2015

4. Paris attacks 2015 (France)

5. Orlando Shooting 2015 (America)

6. Brussels Bombing 2016 (Belgium)

7. Nice Attack 2016 (France)

8. Quebec City Mosque 2017 (Canada)

9. Manchester Arena bombing 2017 (United Kingdom)

10. Finsbury attack 2017 (United Kingdom)

- The ethnicity of Muslims mentioned in the editorial as:

1. Arab/Middle Easterner

2. Black

3. Asian

4. Hispanic

5. Multiple groups

6. Others

7. None

\subsection{Islamophobic Frames}

- (Scale used that was developed by the Commission on British Muslims and Islamophobia, Runnymede trust $1997^{19}$ )

\footnotetext{
${ }^{19}$ Trust Runnymede, Islamophobia: A Challenge for Us All (London: Runnymede Trust, 1997).
} 


\subsubsection{Frame One Coding (Monolithic or Diverse)}

1. Islam seen as diverse and progressive, with internal differences, debates and development (Open views of Islam)

2. Neutral

3. Islam seen as a single monolithic bloc, static and unresponsive to new realities (Closed views of Islam)

\subsubsection{Frame Two Coding (Enemy or Partner)}

1. Islam seen as an actual or potential partner in joint cooperative enterprises and in the solution of shared problems (Open views of Islam)

2. Neutral

3. Islam seen as violent and aggressive, threatening, supportive of terrorism, engaged in a 'Clash of civilization' (Closed views of Islam)

\subsubsection{Frame Three Coding (Criticism of West Accepted or Rejected)}

1. Criticisms of the 'West' and other cultures are considered and debated (Open views of Islam)

2. Neutral

3. Criticisms made by Islam of the 'West' rejected out of hand (Closed views of Islam)

\subsubsection{Frame Four Coding (Discrimination against Muslims Defended or Criticized)}

1. Debates and Disagreements with Islam do not diminish efforts to combat discrimination and exclusion (Open views of Islam)

2. Neutral

3. Hostility towards Islam used to justify discriminatory practices towards Muslims and exclusion of Muslims from mainstream media (Closed views of Islam)

\subsubsection{Frame Five (Islamophobia seen as a Problem or Natural Phenomenon)}

1. Islamophobia seen as natural (Open views of Islam)

2. Neutral

3. Anti-Muslim hostility accepted as natural and 'normal' (Closed views of Islam)

\subsection{Imagery of Islam/Muslims Presented in the Context of Terrorism}

1. Highly negative

$$
\text { (Likert Scale) }
$$

2. Negative

3. Neutral

4. Highly positive

5. Positive

\section{Results}

The chart highlights the racial/religious profiling of Muslims in the context of terrorism or terror acts. 


\begin{tabular}{|c|c|c|c|c|c|c|c|c|}
\hline \multicolumn{9}{|c|}{ Newspaper 'Mustam_eflinicity Cresstabikation } \\
\hline & & \multicolumn{6}{|c|}{ Wostim_ethinitry } & \multirow[b]{2}{*}{ Tobal } \\
\hline & & $\begin{array}{l}\text { Eabuliddo } \\
\text { Easteresi }\end{array}$ & siacs. & Asian & $\begin{array}{l}\text { Mulipter } \\
\text { greups }\end{array}$ & Othara & hions & \\
\hline \multirow[t]{6}{*}{ Diawspapar } & Tot & 1 & 0 & 4 & $\sigma$ & 1 & 8 & 12 \\
\hline & Exprass titeune & 5 & 1 & 9 & 10 & 1 & 8 & 34 \\
\hline & The guzesan & 5 & 0 & 2 & 6 & D & 17 & 31 \\
\hline & Daily Neas & 7 & 0 & 2 & 6 & 8 & s & 23 \\
\hline & Toroctosun & 9 & $t$ & 1 & 2 & 1 & 13 & 27 \\
\hline & The natonat & 9 & a. & 4 & 4 & 3 & 9 & 28 \\
\hline Totai & & 37 & 2 & 22 & 28 & 6 & 63 & 158 \\
\hline
\end{tabular}

Figure 1. Muslim Ethnicity Mentioned in Editorials

This table highlights that a higher frequency of editorials did not mention the ethnicity of Muslims and hence fall in 'The none category' (63 out of 158 editorials), followed by Arab/Middle Easterner (37 out of 158 editorials), Multiple groups (28 out of 158 editorials), Asians (22 out of 158 editorials), others (6 out of 158 editorials) and Black (2 out of 158 editorials).

\begin{tabular}{|c|c|c|c|c|c|c|}
\hline \multicolumn{6}{|c|}{$\mathrm{IF}_{-} 1$} & \multirow[b]{2}{*}{ Total } \\
\hline & & & Diverse & Neutral & Monolithic & \\
\hline \multirow[t]{24}{*}{ Newspaper } & TOI & Count & 1 & 6 & 7 & 14 \\
\hline & & $\%$ within Newspaper & $7.1 \%$ & $42.9 \%$ & $50.0 \%$ & $100.0 \%$ \\
\hline & & $\%$ within IF_1 & $1.7 \%$ & $9.4 \%$ & $19.4 \%$ & $8.9 \%$ \\
\hline & & $\%$ of Total & $0.6 \%$ & $3.8 \%$ & $4.4 \%$ & $8.9 \%$ \\
\hline & Express tribune & Count & 23 & 11 & 0 & 34 \\
\hline & & $\%$ within Newspaper & $67.6 \%$ & $32.4 \%$ & $0.0 \%$ & $100.0 \%$ \\
\hline & & \% within IF_1 & $39.7 \%$ & $17.2 \%$ & $0.0 \%$ & $21.5 \%$ \\
\hline & & $\%$ of Total & $14.6 \%$ & $7.0 \%$ & $0.0 \%$ & $21.5 \%$ \\
\hline & The guardian & Count & 9 & 16 & 6 & 31 \\
\hline & & $\%$ within Newspaper & $29.0 \%$ & $51.6 \%$ & $19.4 \%$ & $100.0 \%$ \\
\hline & & $\%$ within IF_1 & $15.5 \%$ & $25.0 \%$ & $16.7 \%$ & $19.6 \%$ \\
\hline & & $\%$ of Total & $5.7 \%$ & $10.1 \%$ & $3.8 \%$ & $19.6 \%$ \\
\hline & Daily News & Count & 1 & 18 & 4 & 23 \\
\hline & & $\%$ within Newspaper & $4.3 \%$ & $78.3 \%$ & $17.4 \%$ & $100.0 \%$ \\
\hline & & \% within IF_ 1 & $1.7 \%$ & $28.1 \%$ & $11.1 \%$ & $14.6 \%$ \\
\hline & & $\%$ of Total & $0.6 \%$ & $11.4 \%$ & $2.5 \%$ & $14.6 \%$ \\
\hline & Toronto Sun & Count & 3 & 5 & 19 & 27 \\
\hline & & $\%$ within Newspaper & $11.1 \%$ & $18.5 \%$ & $70.4 \%$ & $100.0 \%$ \\
\hline & & $\%$ within IF_1 & $5.2 \%$ & $7.8 \%$ & $52.8 \%$ & $17.1 \%$ \\
\hline & & $\%$ of Total & $1.9 \%$ & $3.2 \%$ & $12.0 \%$ & $17.1 \%$ \\
\hline & The national & Count & 21 & 8 & 0 & 29 \\
\hline & & $\%$ within Newspaper & $72.4 \%$ & $27.6 \%$ & $0.0 \%$ & $100.0 \%$ \\
\hline & & \% within IF_1 & $36.2 \%$ & $12.5 \%$ & $0.0 \%$ & $18.4 \%$ \\
\hline & & $\%$ of Total & $13.3 \%$ & $5.1 \%$ & $0.0 \%$ & $18.4 \%$ \\
\hline \multirow[t]{4}{*}{ Total } & & Count & 58 & 64 & 36 & 158 \\
\hline & & $\%$ within Newspaper & $36.7 \%$ & $40.5 \%$ & $22.8 \%$ & $100.0 \%$ \\
\hline & & $\%$ within IF_ 1 & $100.0 \%$ & $100.0 \%$ & $100.0 \%$ & $100.0 \%$ \\
\hline & & $\%$ of Total & $36.7 \%$ & $40.5 \%$ & $22.8 \%$ & $100.0 \%$ \\
\hline
\end{tabular}

Figure 2. Monolithic and Diverse Frame 1

IF 1 reflects that in the context of post-terrorist attacks, Monolithic Frames (Closed views of Islam) were more prominent in Toronto Sun (52.8 percent), followed by TOI (19.4 
percent) and The Guardian (19.4 percent). On the other hand, Diverse Frames (Open views of Islam) were more prominent in The Express Tribune (39.7 percent), followed by The National (36.2 percent).

\begin{tabular}{|c|c|c|c|c|c|c|}
\hline \multicolumn{7}{|c|}{ Newspaper *IF_2 Crosstabulation } \\
\hline & & & \multicolumn{3}{|c|}{ IF_2 } & \multirow[b]{2}{*}{ Total } \\
\hline & & & Partner & Neutral & Enemy & \\
\hline \multirow[t]{24}{*}{ Newspaper } & TOI & Count & 4 & 4 & 6 & 14 \\
\hline & & $\%$ within Newspaper & $28.6 \%$ & $28.6 \%$ & $42.9 \%$ & $100.0 \%$ \\
\hline & & $\%$ within IF_2 & $10.8 \%$ & $6.2 \%$ & $10.7 \%$ & $8.9 \%$ \\
\hline & & $\%$ of Total & $2.5 \%$ & $2.5 \%$ & $3.8 \%$ & $8.9 \%$ \\
\hline & Express tribune & Count & 7 & 27 & 0 & 34 \\
\hline & & $\%$ within Newspaper & $20.6 \%$ & $79.4 \%$ & $0.0 \%$ & $100.0 \%$ \\
\hline & & $\%$ within IF_2 & $18.9 \%$ & $41.5 \%$ & $0.0 \%$ & $21.5 \%$ \\
\hline & & $\%$ of Total & $4.4 \%$ & $17.1 \%$ & $0.0 \%$ & $21.5 \%$ \\
\hline & The guardian & Count & 9 & 10 & 12 & 31 \\
\hline & & $\%$ within Newspaper & $29.0 \%$ & $32.3 \%$ & $38.7 \%$ & $100.0 \%$ \\
\hline & & $\%$ within IF_2 & $24.3 \%$ & $15.4 \%$ & $21.4 \%$ & $19.6 \%$ \\
\hline & & $\%$ of Total & $5.7 \%$ & $6.3 \%$ & $7.6 \%$ & $19.6 \%$ \\
\hline & Daily News & Count & 0 & 7 & 16 & 23 \\
\hline & & $\%$ within Newspaper & $0.0 \%$ & $30.4 \%$ & $69.6 \%$ & $100.0 \%$ \\
\hline & & $\%$ within IF_2 & $0.0 \%$ & $10.8 \%$ & $28.6 \%$ & $14.6 \%$ \\
\hline & & $\%$ of Total & $0.0 \%$ & $4.4 \%$ & $10.1 \%$ & $14.6 \%$ \\
\hline & Toronto Sun & Count & 1 & 6 & 20 & 27 \\
\hline & & $\%$ within Newspaper & $3.7 \%$ & $22.2 \%$ & $74.1 \%$ & $100.0 \%$ \\
\hline & & $\%$ within IF_2 & $2.7 \%$ & $9.2 \%$ & $35.7 \%$ & $17.1 \%$ \\
\hline & & $\%$ of Total & $0.6 \%$ & $3.8 \%$ & $12.7 \%$ & $17.1 \%$ \\
\hline & The national & Count & 16 & 11 & 2 & 29 \\
\hline & & $\%$ within Newspaper & $55.2 \%$ & $37.9 \%$ & $6.9 \%$ & $100.0 \%$ \\
\hline & & $\%$ within IF_2 & $43.2 \%$ & $16.9 \%$ & $3.6 \%$ & $18.4 \%$ \\
\hline & & $\%$ of Total & $10.1 \%$ & $7.0 \%$ & $1.3 \%$ & $18.4 \%$ \\
\hline \multirow[t]{4}{*}{ Total } & & Count & 37 & 65 & 56 & 158 \\
\hline & & $\%$ within Newspaper & $23.4 \%$ & $41.1 \%$ & $35.4 \%$ & $100.0 \%$ \\
\hline & & $\%$ within IF_2 & $100.0 \%$ & $100.0 \%$ & $100.0 \%$ & $100.0 \%$ \\
\hline & & $\%$ of Total & $23.4 \%$ & $41.1 \%$ & $35.4 \%$ & $100.0 \%$ \\
\hline
\end{tabular}

Figure 3. Enemy and Partner Frame 2

IF 2 reflects that in the context of post-terrorist attacks, Enemy Frames (Closed views of Islam) were more prominent in Toronto Sun (35.7 percent) followed by Daily News (28.6 percent) and TOI (10.7 percent).

On the other hand, Partner Frames (Open views of Islam) were more prominent in The National (43.2 percent), followed by The Guardian (24.3 percent), followed by and The Express Tribune (18.9 percent).

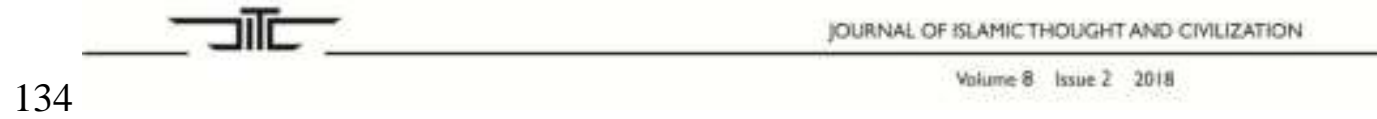


Newspaper 'If_ 4 Crosstabulation

\begin{tabular}{|c|c|c|c|c|c|c|}
\hline & & & & IF_4 & & \\
\hline & & & $\begin{array}{c}\text { Discriminatio } \\
\text { n criticized }\end{array}$ & neutral & $\begin{array}{c}\text { Discriminatio } \\
\text { n defended }\end{array}$ & Total \\
\hline Newspaper & TOI & Count & 7 & 6 & 1 & 14 \\
\hline & & $\%$ within Newspaper & $50.0 \%$ & $42.9 \%$ & $7.1 \%$ & $100.0 \%$ \\
\hline & & $\%$ within IF_4 & $13.2 \%$ & $6.9 \%$ & $5.6 \%$ & $8.9 \%$ \\
\hline & & $\%$ of Total & $4.4 \%$ & $3.8 \%$ & $0.6 \%$ & $8.9 \%$ \\
\hline & Express tribune & Count & 8 & 26 & 0 & 34 \\
\hline & & \% within Newspaper & $23.5 \%$ & $76.5 \%$ & $0.0 \%$ & $100.0 \%$ \\
\hline & & \% within IF_4 & $15.1 \%$ & $29.9 \%$ & $0.0 \%$ & $21.5 \%$ \\
\hline & & $\%$ of Total & $5.1 \%$ & $16.5 \%$ & $0.0 \%$ & $21.5 \%$ \\
\hline & The guardian & Count & 17 & 13 & 1 & 31 \\
\hline & & $\%$ within Newspaper & $54.8 \%$ & $41.9 \%$ & $3.2 \%$ & $100.0 \%$ \\
\hline & & $\%$ within If_ 4 & $32,1 \%$ & $14.9 \%$ & $5.6 \%$ & $19.6 \%$ \\
\hline & & $\%$ of Total & $10.8 \%$ & $8.2 \%$ & $0.6 \%$ & $19.6 \%$ \\
\hline & Daily News & Count & 2 & 14 & 7 & 23 \\
\hline & & $\%$ within Newspaper & $8.7 \%$ & $60.9 \%$ & $30.4 \%$ & $100.0 \%$ \\
\hline & & $\%$ within IF_4 & $3.8 \%$ & $16.1 \%$ & $38.9 \%$ & $14.6 \%$ \\
\hline & & $\%$ of Total & $1.3 \%$ & $8.9 \%$ & $4.4 \%$ & $14.6 \%$ \\
\hline & Toronto Sun & Count & 8 & 11 & 8 & 27 \\
\hline & & $\%$ within Newspaper & $29.6 \%$ & $40.7 \%$ & $29.6 \%$ & $100.0 \%$ \\
\hline & & $\%$ within IF_4 & $15.1 \%$ & $12.6 \%$ & $44.4 \%$ & $17.1 \%$ \\
\hline & & $\%$ of Total & $5.1 \%$ & $7.0 \%$ & $5.1 \%$ & $17.1 \%$ \\
\hline & The national & Count & 11 & 17 & 1 & 29 \\
\hline & & \% within Newspaper & $37.9 \%$ & $58.6 \%$ & $3.4 \%$ & $100.0 \%$ \\
\hline & & $\%$ within IF_4 & $20.8 \%$ & $19.5 \%$ & $5.6 \%$ & $18,4 \%$ \\
\hline & & $\%$ of Total & $7.0 \%$ & $10.8 \%$ & $0.6 \%$ & $18.4 \%$ \\
\hline Total & & Count & 53 & 87 & 18 & 158 \\
\hline & & $\%$ within Newspaper & $33.5 \%$ & $55.1 \%$ & $11,4 \%$ & $100.0 \%$ \\
\hline & & $\%$ within If_4 & $100.0 \%$ & $100.0 \%$ & $100.0 \%$ & $100.0 \%$ \\
\hline & & $\%$ of Total & $33.5 \%$ & $55.1 \%$ & $11.4 \%$ & $100.0 \%$ \\
\hline
\end{tabular}

Figure 4. Criticism of West Accepted or Rejected Frame 3

IF 3 reflects that in the context of post-terrorist attacks, Criticism of west rejected Frames (Closed views of Islam) was more prominent in Toronto Sun (44.4 percent), followed by Daily News (38.9 percent). On the other hand, Criticism of West accepted Frames (Open views of Islam) were more prominent in The Guardian (32.1 percent), followed by The National (20.8 percent). 


\begin{tabular}{|c|c|c|c|c|c|c|}
\hline & & & \multicolumn{3}{|c|}{ If I $_{4}$} & \multirow[b]{2}{*}{ Total } \\
\hline & & & $\begin{array}{c}\text { Discriminatio } \\
\text { n criticizad }\end{array}$ & neutral & $\begin{array}{c}\text { Discriminatio } \\
\text { n defended }\end{array}$ & \\
\hline \multirow[t]{24}{*}{ Nowspaper } & TOI & Count & 7 & 6 & 1 & 14 \\
\hline & & \% within Newspaper & $50.0 \%$ & $42.9 \%$ & $7.1 \%$ & $100.0 \%$ \\
\hline & & $\%$ within IF_4 & $13.2 \%$ & $6.9 \%$ & $5.6 \%$ & $8.9 \%$ \\
\hline & & $\%$ of Total & $4.4 \%$ & $3.8 \%$ & $0.6 \%$ & $8.9 \%$ \\
\hline & Express tribune & Count & g & 26 & 0 & 34 \\
\hline & & $\%$ within Newspaper & $23.5 \%$ & $76.5 \%$ & $0.0 \%$ & $100.0 \%$ \\
\hline & & 96 within IF -4 & $15.1 \%$ & $29.9 \%$ & $0.0 \%$ & $21.5 \%$ \\
\hline & & 96 of Total & $5.1 \%$ & $16.5 \%$ & $0.0 \%$ & $21.5 \%$ \\
\hline & The guardian & Count & 17 & 13 & 1 & 31 \\
\hline & & \% within Newspaper & $54.8 \%$ & $41.9 \%$ & $3.2 \%$ & $100.0 \%$ \\
\hline & & 96 within If_4 & $32.1 \%$ & $14.9 \%$ & $5.6 \%$ & $19.6 \%$ \\
\hline & & $\%$ of Total & $10.8 \%$ & $8.2 \%$ & $0.6 \%$ & $19.6 \%$ \\
\hline & Daily News & Count & 2 & 14 & 7 & 23 \\
\hline & & \% within Newspaper & $8.7 \%$ & $60.9 \%$ & $30.4 \%$ & $100.0 \%$ \\
\hline & & \% within IF_4 & $3.8 \%$ & $16: 1 \%$ & $38.9 \%$ & $14.6 \%$ \\
\hline & & $\% 6$ of Total & $1.3 \%$ & $8.9 \%$ & $4.4 \%$ & $14.6 \%$ \\
\hline & Toronto Sun & Count & B & 11 & 8 & 27 \\
\hline & & \% within Newspaper & $29.6 \%$ & $40.7 \%$ & $29.6 \%$ & $100.0 \%$ \\
\hline & & 96 within IF_4 & $15.1 \%$ & $12.6 \%$ & $44.4 \%$ & $17.1 \%$ \\
\hline & & $\%$ of Total & $5.1 \%$ & 7.096 & $5.1 \%$ & $17.1 \%$ \\
\hline & The national & count & 11 & 17 & 1 & 29 \\
\hline & & \% within Newspaper & $37.9 \%$ & $58.6 \%$ & $3,4 \%$ & $100.0 \%$ \\
\hline & & $\%$ within if _ 4 & $20.8 \%$ & $19.5 \%$ & $5.6 \%$ & $18.4 \%$ \\
\hline & & $\%$ of Total & $7.0 \%$ & $10.8 \%$ & $0.6 \%$ & $18.4 \%$ \\
\hline \multirow{4}{*}{\multicolumn{2}{|c|}{ Total }} & Count & 53 & 87 & 18 & 158 \\
\hline & & \% within Newspaper & $33.5 \%$ & $56.1 \%$ & $11.4 \%$ & $100.0 \%$ \\
\hline & & \% within IF_4 & $100,0 \%$ & $100.0 \%$ & $100.0 \%$ & $100.0 \%$ \\
\hline & & $\%$ of Total & $33.5 \%$ & $58.1 \%$ & $11.4 \%$ & $100.0 \%$ \\
\hline
\end{tabular}

Figure 5. Discrimination against Muslims Defended and Criticized Frame 4

IF 4 reflects that in the context of post-terrorist attacks, Discrimination defended Frames (Closed views of Islam) were more prominent in Toronto Sun (44.4 percent), followed by Daily News (38.9 percent). On the other hand, Discrimination criticized Frames (Open views of Islam) were more prominent in The Guardian (32.1 percent), followed by The National (20.8 percent) and Toronto Sun with Express Tribune (15.1 percent).

\begin{tabular}{|c|c|c|c|c|c|c|}
\hline & & & \multicolumn{3}{|c|}{$11-5$} & \multirow[b]{2}{*}{ Total } \\
\hline & & & $\begin{array}{l}\text { Salamophobia } \\
\text { sesn as a } \\
\text { problem }\end{array}$ & neutral & $\begin{array}{l}\text { Seen as } \\
\text { natural }\end{array}$ & \\
\hline \multirow[t]{24}{*}{ Nowspaper } & Tol & Count & 6 & 2 & 6 & 14 \\
\hline & & \%) within Newspaper & $42.9 \%$ & $14.3 \%$ & $42.9 \%$ & $100.0 \%$ \\
\hline & & 96 within IF_s & $16.7 \%$ & $4.9 \%$ & $7.4 \%$ & 8.99 \\
\hline & & \$6 of Total & $3.8 \%$ & 1,396 & 3.896 & 8.996 \\
\hline & Express tribune & Count & 8 & 21 & 5 & 34 \\
\hline & & \$6 within Newspaper & $23.5 \%$ & $81.8 \%$ & $14.7 \%$ & $100.0 \%$ \\
\hline & & \% within IF_s & $22.2 \%$ & $51.2 \%$ & $6.2 \%$ & $21.6 \%$ \\
\hline & & \% of Total & $5.1 \%$ & $13.3 \%$ & $3.2 \%$ & 21.59 \\
\hline & The guardian & Count & 9 & 5 & 17 & 31 \\
\hline & & \% within Newspaper & $29.0 \%$ & $16.1 \%$ & $54.8 \%$ & $100.0 \%$ \\
\hline & & \% within If_ 5 & $25.0 \%$ & $12.2 \%$ & $21.0 \%$ & $18.6 \%$ \\
\hline & & \% of Total & $5.7 \%$ & $3.2 \%$ & $10.8 \%$ & $19.6 \%$ \\
\hline & Daily News & count & 0 & 8 & 15 & 23 \\
\hline & & $\%$ within Newspaper & $0.0 \%$ & $34.8 \%$ & $65.2 \%$ & $100.0 \%$ \\
\hline & & \%o within If_s & $0.0 \%$ & $10.6 \%$ & $18.6 \%$ & $14.6 \%$ \\
\hline & & 96 of Total & $0.0 \%$ & $5.1 \%$ & $9.5 \%$ & 14.69 \\
\hline & Toronto Eun & Count & 3 & 0 & 24 & 27 \\
\hline & & $\%$ within Newspaper & $11.1 \%$ & $0.0 \%$ & 日8.9\% & $100.0 \%$ \\
\hline & & \%o within If_s & $8.3 \%$ & $0.0 \%$ & $29.6 \%$ & $17.1 \%$ \\
\hline & & $\%$ of Total & $1.9 \%$ & $0.0 \%$ & $15.2 \%$ & $17.1 \mathrm{x}$ \\
\hline & The national & Count & 10 & $G$ & 14 & 26 \\
\hline & & 96 within Nowspapor & $34.5 \%$ & $17.2 \%$ & $483 \%$ & $100.0 \%$ \\
\hline & & No within If_-5 & $27.8 \%$ & $12.2 \%$ & $17.3 \%$ & $18.4 \%$ \\
\hline & & 96 of Total & $6.3 \%$ & $3.2 \%$ & a.9\% & $18.4 \%$ \\
\hline \multirow{4}{*}{\multicolumn{2}{|c|}{ Total }} & Count & 36 & 41 & 81 & 158 \\
\hline & & \% within Nowspaper & $220 \%$ & $25.9 \%$ & $51,3 \%$ & $100.0 \%$ \\
\hline & & W6 within If -5 & $100.0 \%$ & $100.0 \%$ & $100.0 \%$ & $100.0 \%$ \\
\hline & & $\%$ of Total & $228 \%$ & $25.9 \%$ & $51.3 \%$ & $100,0 \%$ \\
\hline
\end{tabular}

Figure 6. Islamophobia seen as Natural or Problem Frame 5 
IF 5 reflects that in the context of post-terrorist attacks, Islamophobia seen as natural Frames (Closed views of Islam) were more prominent in Toronto Sun (29.6 percent), followed by The Guardian (21.0 percent), Daily News (18.5 percent). On the other hand, Islamophobia seen as a problem Frames (Open views of Islam) were more prominent in The National (27.8 percent), followed by Express Tribune (22.2 percent). The total frequency of press coverage highlights that the presence of closed frames (51.3 percent) was higher in comparison to neutral frames (25.9 percent) and closed Frames (22.8 percent) respectively.

One way Anova was applied to the Likert scale Question to find out whether any association or relationship was observed within the news coverage of these newspapers in the light of Muslim imagery building in the context of Terrorism.

ANOVA

Imagery_of_Muslims_in_context_of_terrorism
\begin{tabular}{|l|r|r|r|r|r|}
\hline & \multicolumn{1}{|c|}{$\begin{array}{c}\text { Sum of } \\
\text { Squares }\end{array}$} & \multicolumn{1}{c|}{ df } & Mean Square & \multicolumn{1}{c|}{ F } & \multicolumn{1}{c|}{ Sig. } \\
\hline Between Groups & 51.013 & 5 & 10.203 & 11.225 & .000 \\
Within Groups & 138.158 & 152 & .909 & & \\
Total & 189.171 & 157 & & & \\
\hline
\end{tabular}

Figure 7. Anova Results on the Imagery of Muslims Presented in the Context of Terrorism

\begin{tabular}{|c|c|c|c|c|c|c|}
\hline \multicolumn{7}{|c|}{ Multiple Comparisons } \\
\hline \multicolumn{7}{|c|}{$\begin{array}{l}\text { Dependent Variable: Imagery_of_Muslims_in_context_of_terrorism } \\
\text { TukeyHSD }\end{array}$} \\
\hline \multirow[b]{2}{*}{ (1) Newspaper } & \multirow[b]{2}{*}{ (J) Nowspaper } & \multirow{2}{*}{$\begin{array}{l}\text { Mean } \\
\text { Difference (1- } \\
\mathrm{J})\end{array}$} & \multirow[b]{2}{*}{ Std Error } & \multirow[b]{2}{*}{ sig. } & \multicolumn{2}{|c|}{$95 \%$ Confidence Interval } \\
\hline & & & & & Lower Bound & Upper Bound \\
\hline \multirow[t]{5}{*}{ TOI } & Express tribune & -.77311 & 30275 & 116 & -1.6470 & 1008 \\
\hline & The guardian &,- 18203 & 30699 & 991 & -1.0681 & 7041 \\
\hline & Daily News & .74224 & .32318 & 202 & -.1906 & 1.6751 \\
\hline & Toronto sun & .56349 & .31399 & .472 & -.3428 & 1.4698 \\
\hline & The national &., 59360 & 31027 & 398 & $-1,4892$ & 3020 \\
\hline \multirow[t]{5}{*}{ Express tribune } & TOl & .77311 & .30275 & 115 & -.1008 & 1.6470 \\
\hline & The guardian & 59108 & 23676 & 132 & -.0923 & 1.2745 \\
\hline & Daily News & $1.51535^{\circ}$ & 25740 & 000 & .7724 & 2.2583 \\
\hline & Toronto Sun & $1.33660^{\circ}$ & 24576 & .000 & 6272 & 2.0460 \\
\hline & The national & 17951 & 24099 & 978 &. .5161 & .8751 \\
\hline \multirow[t]{5}{*}{ The guardian } & TOI & 18203 & 30699 & 991 & -.7041 & 1.0681 \\
\hline & Express tribune & -.59108 & 23676 & 132 & -1.2745 & .0923 \\
\hline & Dally News & $92426^{\circ}$ & 26237 & 007 & 1669 & 1.6816 \\
\hline & Toronto sun & $74552^{\circ}$ & 25097 & 040 & .0211 & 1.4699 \\
\hline & The national & -.41157 & .24630 & .553 & -1.1225 & .2994 \\
\hline \multirow[t]{5}{*}{ Dally News } & TOI & .74224 & 32318 & 202 & $-1,6751$ & 1906 \\
\hline & Express tribune & $-1.51535^{\circ}$ & .25740 & .000 & -2.2583 & -.7724 \\
\hline & The guardian & $-.92426^{\circ}$ & 26237 & 007 & -1.6816 & -.1669 \\
\hline & Toronto sun & -17874 & .27052 & 986 & -9596 & 6021 \\
\hline & The national & $-1.33583^{*}$ & .26620 & .000 & -2.1042 & -.5675 \\
\hline \multirow[t]{5}{*}{ Toronto Sun } & TOl & -.56349 & .31399 & 472 & -1.4698 & .3428 \\
\hline & Express tribune & $-1.33660^{\circ}$ & 24576 & 000 & -2.0460 & -6272 \\
\hline & The guardian & $-.74552^{\circ}$ & 25097 & .040 & -1.4699 & -.0211 \\
\hline & Daily News & 17874 & 27052 & 986 & -.6021 & .9596 \\
\hline & The national & $-1.15709^{\circ}$ & 25496 & 000 & -1.8930 & -.4212 \\
\hline \multirow[t]{5}{*}{ The national } & TOI & .59360 & .31027 & 398 & -.3020 & 1.4892 \\
\hline & Express tribune & -17951 & 24099 & 976 &. .9751 & 5161 \\
\hline & The guardian & .41157 & .24630 & 553 & -.2994 & 1.1225 \\
\hline & Daily News & $1.33583^{\circ}$ & 26620 & 000 & .5675 & 2.1042 \\
\hline & Toronto sun & $1,15709^{\circ}$ & .25496 & 000 & 4212 & 1.8930 \\
\hline
\end{tabular}

*. The mean difference is significant at the 0.05 level.

Figure 8. Results of the Imagery of Muslims presented in the Context of Terrorism 
Tariq and Hanan Terrorism and Racial Profiling

This table highlights that each newspaper has significant differences with other newspapers in relation to the imagery building or representation of Muslims/Islam in the context of terrorism or terror acts in their news coverage.

TOI has no significant difference with the other five newspapers (Toronto Sun, Daily News, Express Tribune, The Guardian and The National) in the representation of Islam and Muslims in the context of terrorism. Significant differences were observed within the news coverage of Express Tribune with Daily News and Toronto Sun. Significant differences were observed within the news coverage of The Guardian with Daily News and Toronto Sun. Significant differences were observed within the news coverage of Daily News with The Express Tribune, The Guardian and The National. Significant differences were observed within the news coverage of Toronto Sun with Express Tribune, The Guardian and The National. Significant differences were observed within the news coverage of The National with Daily News and Toronto Sun.

\begin{tabular}{|c|c|c|c|c|}
\hline \multicolumn{5}{|c|}{ Muslim Imagery in the Context of Terrorism } \\
\hline \multicolumn{5}{|l|}{ Tukey HSD $^{a, b}$} \\
\hline \multirow{2}{*}{ Newspaper } & \multirow[b]{2}{*}{$\mathrm{N}$} & \multicolumn{2}{|c|}{ Subset for alpha $=0.05$} & \multirow[b]{2}{*}{3} \\
\hline & & 1 & 2 & \\
\hline Daily News & 23 & 2.0435 & 0.0000 & 0.0000 \\
\hline Toronto Sun & 27 & 2.2222 & 2.2222 & 0.0000 \\
\hline \multirow{2}{*}{$\begin{array}{l}\text { TOI } \\
\text { The guardian }\end{array}$} & 14 & 2.7857 & 2.7857 & 2.7857 \\
\hline & 31 & 0.0000 & 2.9677 & 2.9677 \\
\hline \multirow{2}{*}{$\begin{array}{l}\text { The national } \\
\text { Express tribune }\end{array}$} & 29 & 0.0000 & 0.0000 & 3.3793 \\
\hline & 34 & 0.0000 & 0.0000 & 3.5588 \\
\hline Sig. & & .080 & .077 & .060 \\
\hline
\end{tabular}

Means for groups in homogeneous subsets are displayed.

a. Uses Harmonic Mean Sample Size $=24.184$.

b. The group sizes are unequal. The harmonic mean of the group sizes is used. Type I error levels are not guaranteed.

The Post-Hoc Tukey test highlights the degree of association within the news coverage of Muslims/Islam in the context of terrorism or terror acts in each newspaper. Set $1(\mathrm{~N}=1)$ highlights that no significant association was observed within the news coverage of Daily news with set 2 and 3(TOI, The Guardian, The National, Express Tribune) respectively. Set $1(\mathrm{~N}=1)$ also highlights that no significant association was observed within the news coverage of Toronto Sun and set 3 (The National, Express Tribune) respectively. Set $2(\mathrm{~N}=2)$ highlights that no significant association was observed in the news coverage of The Guardian and Set 1 (Daily News and Toronto Sun) respectively. Set $3(\mathrm{~N}=3)$ highlights that no significant association was observed within the news coverage of The National and Set 1 and 2 (Daily News, Toronto Sun, TOI, The Guardian) respectively. Set $3(\mathrm{~N}=3)$ also highlights that no significant association was observed within the news coverage of Express tribune and the news coverage of Set 1 and 2 (Daily News, Toronto Sun, TOI, The Guardian).

138

JOURNAL OF ISLAMICTHOUCHT AND CIMLIZATION

Vohime 8 Issue 2 2018 
Newspaper * Imagery_of_Muslims_in_context_of_terrorism Crosstabulation

\begin{tabular}{|c|c|c|c|c|c|c|c|c|}
\hline & & & \multicolumn{5}{|c|}{ Imagery_of_Muslims_in_context_of_terrorism } & \multirow[b]{2}{*}{ Total } \\
\hline & & & $\begin{array}{c}\text { Highly } \\
\text { negative }\end{array}$ & Negative & Neutral & Positive & $\begin{array}{l}\text { Highly } \\
\text { Positive }\end{array}$ & \\
\hline \multirow[t]{12}{*}{ Newspaper } & TOI & Count & 2 & 4 & 3 & 5 & 0 & 14 \\
\hline & & $\%$ within Newspaper & $14.3 \%$ & $28.6 \%$ & $21.4 \%$ & $35.7 \%$ & $0.0 \%$ & $100.0 \%$ \\
\hline & Express tribune & Count & 0 & 2 & 13 & 17 & 2 & 34 \\
\hline & & $\%$ within Newspaper & $0.0 \%$ & $5.9 \%$ & $38.2 \%$ & $50.0 \%$ & $5.9 \%$ & $100.0 \%$ \\
\hline & The guardian & Count & 0 & 15 & 5 & 8 & 3 & 31 \\
\hline & & $\%$ within Newspaper & $0.0 \%$ & $48.4 \%$ & $16.1 \%$ & $25.8 \%$ & $9.7 \%$ & $100.0 \%$ \\
\hline & Daily News & Count & 6 & 10 & 7 & 0 & 0 & 23 \\
\hline & & $\%$ within Newspaper & $26.1 \%$ & $43.5 \%$ & $30.4 \%$ & $0.0 \%$ & $0.0 \%$ & $100.0 \%$ \\
\hline & Toronto Sun & Count & 6 & 14 & 3 & 3 & 1 & 27 \\
\hline & & $\%$ within Newspaper & $22.2 \%$ & $51.9 \%$ & $11.1 \%$ & $11.1 \%$ & $3.7 \%$ & $100.0 \%$ \\
\hline & The national & Count & 0 & 8 & 5 & 13 & 3 & 29 \\
\hline & & $\%$ within Newspaper & $0.0 \%$ & $27.6 \%$ & $17.2 \%$ & $44.8 \%$ & $10.3 \%$ & $100.0 \%$ \\
\hline \multirow[t]{2}{*}{ Total } & & Count & 14 & 53 & 36 & 46 & 9 & 158 \\
\hline & & $\%$ within Newspaper & $8.9 \%$ & $33.5 \%$ & $22.8 \%$ & $29.1 \%$ & $5.7 \%$ & $100.0 \%$ \\
\hline
\end{tabular}

Figure 9. Imagery of Muslims Presented in the Context of Terrorism

The table highlights the news coverage of Muslims/Islam in the context of terrorism within each newspaper respectively. Negative themes and frames against Muslims/Islam in the context of terrorism were more prominent in Toronto Sun (51.9 percent), The Guardian (48.4 percent) and Daily News (43.5 percent). However, Neutral themes and frames against Muslims/Islam in the context of terrorism were more prominent in TOI (21.4 percent) and Daily News (30.4 percent). Positive themes were more prominent in Express Tribune (50.0 percent) and The National (44.4 percent)

\section{Discussion}

The purpose of this research is to analyze the role of the international press in framing Muslims and Islam in the context of terrorism. The researcher intends to pinpoint and observe the underlying themes and frames present within editorials of leading International newspapers, to seek out whether Islamophobic frames were visible or not. Moreover, the paper examines whether Muslims were profiled on the basis of their ethnicity or religion, after a particular terrorist attack.

\subsection{Research Questions}

\section{RQ 1: What are the significant differences within the press coverage of terrorist attacks?}

The findings of this research highlight that media coverage in the context of terrorist attacks was inconsistent. Terrorist incidents such as the Paris attacks, Charlie Hebdo, Nice Attack and Manchester bombing got maximum coverage in the editorials. Moreover, terrorist incidents such as Finsbury attack and Quebec mosque attack got the least amount of coverage in editorials. Non-Muslims perpetrators were involved in these terrorist attacks and hence an underreporting bias was observed on the part of the international press. The results of this study are consistent with the study of Kern, Just 
and Norris ${ }^{20}$ that highlighted how varying amount of coverage is given to terrorism, where some terrorist's incidents such as Mumbai attacks 2008 in India and 9/11 attack in the USA got the maximum amount of coverage by the media outlets whereas other incidents went away unnoticed.

\section{RQ 2: What is the role of International press coverage in the racial or religious profiling of Muslims globally?}

The results of the study also highlighted that a higher proportion of editorials did not mention the ethnicity of Muslim perpetrators or victims after a terrorist incident. Hence profiling of Muslims on the basis of religion or ethnicity was less visible in editorials. However, a fairly moderate amount of editorials profiled Muslim perpetrators and victims as Arab/Middle Easterner. These results show consistency with the study of Siggins $^{21}$ that pinpoints the findings of a survey in which almost Seventy-One percent Americans and Sixty-Six percent whites approved the use of racial/religious profiling if the person seemed to be of Middle Eastern background. Hence the results indicate that racial and religious profiling of Muslims was moderately visible in the editorials.

\section{RQ 3: Is there any significant association between the news coverage of different newspapers with one another in the context of terrorism?}

Results highlighted that significant differences were observed in the news coverage of different newspapers with one another in the context of terrorism. Negative themes and frames were more noticeable in the editorials of Toronto Sun and Daily News, after a terrorist incident. Positive themes and frames in the favour of Muslims/Islam were more observable in Express Tribune and The National, after a terrorist incident. However Neutral themes and frames (Positive and Negative both) were more prominent in the editorials of The Guardian and TOI, after a terrorist incident. A significant association was detected in the news coverage of Toronto Sun with Daily News, Express Tribune with The National and The Guardian with TOI. Hence significant differences were observed in the news coverage of each newspaper with its rival or competing newspaper.

\section{RQ 4: What is the role of the International press in the proliferation of Islamophobia globally?}

The findings of the research highlighted that closed themes and frames leading to Islamophobic attitudes were more noticeable in the editorials of Toronto Sun and Daily News whereas open themes and frames about Islam were more discernible in The National and Express Tribune However a higher frequency of neutral frames were observed in The Guardian and TOI. Moreover, the results also indicated that the majority of editorials presented Islamophobia as a natural phenomenon (51.3 percent), highlighting the covert machinery operating within the society for the production of such

${ }^{20}$ Montague Kem, Just Marion and Norris Pippa, The lessons of Framing Terrorism. In P. Norris, M. Kern, and M. Just (Eds.), Framing Terrorism (London: Routledge Press, 2003), 281-302.

${ }^{21}$ Peter Siggins, "Racial Profiling in the Age of Terrorism," https://www.scu.edu/ethics/focus-areas/more/resources/racial-profiling-in-an-age-ofterrorism/ (Markula Center for Applied Ethics, 2002) accessed on 13.4.2018.

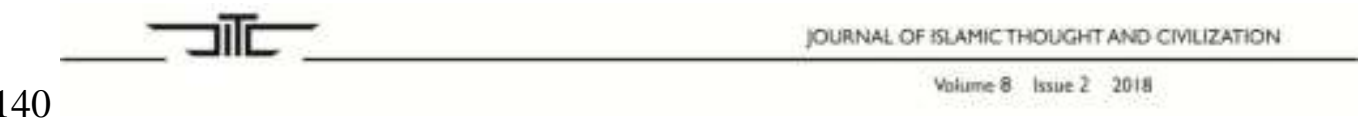


attitudes. These results are consistent with the study of Hockenos ${ }^{22}$ that highlighted how Islam was portrayed as a xenophobic religion by the European media to justify the proliferation of Islamophobic attitudes within Europe.

These individual Islamophobic frames highlight the differences within the editorial policies, social conditions of the country in which the newspapers operate; as well as their respective stances on terrorism. Each newspaper plays a pivotal but individualistic role in either curbing or accelerating the phenomenon of Islamophobia globally.

\section{RQ 5: What is the role of leading press players in creating a relationship between Islam and terrorism globally?}

A higher frequency of Negative frames and themes were used in newspapers (33.5 percent) in comparison to Positive themes (29.1 percent) and Neutral themes (22.8 percent) after a terrorist attack, blaming Muslims as the perpetrators of violence and terror. These results are consistent with the study of Gunning and Jackson ${ }^{23}$ that highlights how researches on terrorism either openly state or infers religion as the root cause of terrorism and how religion is thought to have the power to inspire violence, apart from legitimizing terror. Hence newspapers present a biased imagery of Muslims in the context of terrorism and represent Islam and Muslims as the root cause of escalating violence. The results of this study are consistent with the study of Whittaker ${ }^{24}$ according to which different stereotypical themes appeared persistently from time to time within articles after 9/11. These themes stereotyped Muslims as violent, cruel, bigoted and misogynist.

\section{Results}

The results of this research provide fascinating insights into the role of the International press in the portrayal of Islam and Muslims in the context of terrorism, contributing to an inherently despicable mechanism of racial/religious profiling of Muslims, as perpetrators of terrorism.

The findings of this research highlight how press coverage of various International newspapers were incoherent. Disparities were visible in the coverage of terrorist activities with Muslim involvement and non-Muslim involvement. Incidents such as Finsbury attack and Quebec mosque attack got the least amount of space in editorials. However, Paris attacks, Charlie Hebdo, Nice Attack and Manchester bombing got the maximum amount of coverage in leading editorials. Moreover, a higher number of editorials did not mention the ethnicity of the perpetrator and even the victims after any particular terrorist attack. However, references of Muslim ethnicity were highest in Express Tribune and the lowest in TOI. These findings highlight that profiling of Muslims on the basis of their religious beliefs or ethnicity were less discernible in editorials.

\footnotetext{
${ }^{22}$ Paul Hockenos, "Europe's Rising Islamophobia," The Nation, April 13, 2011.

${ }^{23}$ Jeroen Gunning and Richard Jackson, "What's so 'Religious' about 'Religious Terrorism,"” Critical Studies on Terrorism 4 (2011): 369-388.

${ }^{24}$ Brain Whittaker, "Islam and the British Press after 9/11," https://albab.com/special-topics/islam-and-british-press-after-september-11 accessed 13.4.2018.
} 
The findings of this research also indicate that news frames as well as the tone of the editorials were neutral in the context of islamophobia, followed by closed views and open views respectively. These results were based on the aggregate total of the findings, however, individual frequencies of the editorials highlighted a higher frequency of islamophobic frames. Closed themes and views were more prominent in Toronto Sun whereas open themes and frames about Islam were more discernible in The National. Hence the findings highlight that each newspaper plays a pertinent and distinctive role in the propagation of Islamophobic attitudes, which highlights how Islamophobia is penetrating in the western social order leading to racial discrimination practices as well as fear and hatred against Muslims at large. Results also highlighted that substantial inconsistencies were detected in the press coverage of Islam and Muslims in the milieu of terrorism. Negative and biased themes were more visible in the editorials of Toronto Sun and Daily News whereas positive themes and tones were more discernible in Express Tribune and The National.

A significant relationship was also identified in the press coverage of The Guardian with TOI, Toronto sun with Daily News, and Express Tribune with The National. Hence significant dissimilarities were observed within the press coverage of each newspaper with its competitor.

\section{Bibliography}

Allen, Christopher. "Islamophobia." Surrey, UK: Ashgate Publishing Group, 2010.

Bilgen, Arda. "Terrorism and the Media: A Dangerous Symbiosis." Retrieved from http://www.e-ir.info/2012/07/22/terrorism-and-the-media-a-dangeroussymbiosis/. (2012)

Buerger, Michael. "Racial Profiling.” In J. M. Miller, 21st Century Criminology: A Reference Handbook. 741-749. Thousand Oaks, 2009.

Cavanaugh, William T. The Myth of Religious Violence: Secular Ideology and the Roots of Modern Conflict. NY, America: Oxford University Press, 2009.

Cole, David. Enemy Aliens. Double Standards and Constitutional Freedoms in the War on Terrorism. New York, USA: New Press, Distributed by W. W. Norton, 2005.

Edelman, Murray. Constructing the Political Spectacle. Chicago, IL: University of Chicago Press, 1988.

El-Fadl, Khaled Abou. "Terrorism is at Odds with Islamic Tradition." The Los Angeles Times 22 September 2001.

Gitlin, Todd. The Whole World is watching: Mass Media in the Making and Unmaking of the New Left. Chicago, IL: University of Chicago Press, 2003.

Global Terrorism Index. "Measuring and Understanding the Impact of Terrorism." Institute for Economics and Peace, 2016, http://economicsandpeace.org/wpcontent/uploads/2016/11/Global-Terrorism-Index-2016.2.pdf

Gunning, Jeroen., and Richard Jackson. "What's so 'Religious' about 'Religious Terrorism'?" Critical Studies on Terrorism 4, no. 3 (2011): 369-388.

Hartmann, Paul G., and Charles Husband. Racism and the Mass Media. London: DansPoynter, 1974.

Hoffman, Bruce. Inside Terrorism. New York, USA: Columbia University Press, 2006.

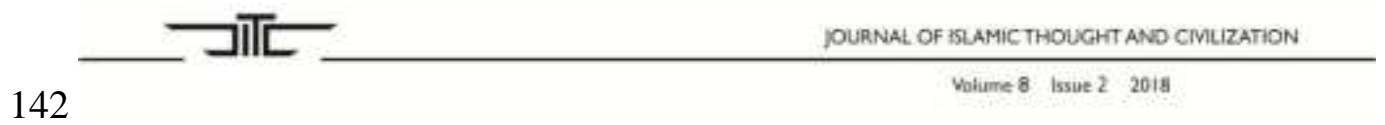


Hsieh, Hsiu-Fang., and Sarah E. Shannon. "Three Approaches to Qualitative Content Analysis." Qualitative Health Research 15 (2005): 1277-1288.

Hurd, Elizabeth Shakman. "Appropriating Islam: The Islamic other in the Consolidation of Western Modernity." Critique: Critical Middle Eastern Studies 12, no. 1 (2003): 25-41.

Islamophobia: A Challenge for us All. London, UK: Runnymede Trust, 1997.

Jackson, Richard. 'Constructing Enemies: 'Islamic Terrorism' in Political and Academic Discourse." Government and Opposition 42, no. 3 (2007): 394-426.

Jameson, Fredric. "The Dialectics of Disaster." In S. Hauerwas, and F. Lentricchia (Editors.), Dissent from the Homeland: Essays after September11. Durham: Duke University Press. The South Atlantic Quarterly 101, no. 2, Special Issue, (2002): 297-304.

Johnson, Deven. Daniel Brazier, Katrina Forrest, Crispin Ketelhut, Darron Mason, and Marc Mitchell. "Attitudes towards the Use of Racial/Ethnic Profiling to Prevent Crime and Terrorism." Criminal Justice Policy Review 22, no. 4 (2011): 422447.

Juergensmeyer, Mark. Terror in the Mind of God: the Global Rise of Religious Violence. Berkeley: University of California Press, 2003.

Juhaya, S. Praja. Islam, Globalization and Counter Terrorism. Available online at http://www.unafei.or.jp/english/pdf/RS_No71/No71_09VE_Praja1.pdf, checked on 11/3/2017. 2003.

Kavoori, Anamdam. P., and Fraley Todd, Media, Terrorism, and Theory. USA: Rowman and Littlefield, 2006.

Kern, Montague. Marion Just, Marion, Pippa Norris. "The Lessons of Framing Terrorism.” In P. Norris, M. Kern, and M. Just. Editors. Framing Terrorism. 281302. London: Routledge, 2003.

Krauthammer, Charles. "The Case for Profiling.” Time Magazine, March 10, 2001.

Kulaszewicz, Kassia E. "Racism and the Media: A Textual Analysis." Master of Social Work Clinical Research Papers, 2015.

Laqueur, Walter. The New Terrorism: Fanaticism and the Arms of Mass Destruction. New York, USA: Oxford University Press, 1999.

Lean, Nathan C. The Islamophobia Industry: How the Right Manufactures Fear of Muslims. (Paperback ed.): Pluto Press, 2012.

Lewis, Bernard. The Crisis of Islam: Holy War and Unholy Terror. New York, America: Random House Trade, 2004.

Manning, Peter. Dog Whistle Politics and Journalism: Reporting Arabic and Muslim People in Sydney Newspapers 2000-2002. Sydney, NSW, Australia: Australian Center for Independent Journalism, 2004.

Ma'nnik, Erik. "Terrorism: Its Past, Present and Future Prospects." Retrieved from http://www.ksk.edu.ee/wp-content/uploads/2011/03/KVUOA_Toimetised_12M\%C3\%A4nnik.pdf website. 2001. 
Nacos, Brigitte. "Terrorism/Counterterrorism and Media in the Age of Global Communication." United Nations University Global Seminar Second Shimame-Yamaguchi Session, 5-8 August 2006.

Onwudiwe, Ihekwoaba D. The Globalization of Terrorism. England: Ashgate Publishing Ltd Hampshire, 2001.

Saad, Lydia. "Anti-Muslim Sentiments Fairly Commonplace. Four in ten Americans Admit Feeling Prejudice against Muslims." Gallup Poll News Service 2006.

Sinai, Joshua. “A Conceptual Framework for Resolving Terrorism's Root Causes." in Root Causes of Terrorism. Myths, Reality and Ways Forward. 215-222. London: Rutledge, 2005.

Siggins, Peter. "Racial Profiling in the Age of Terrorism." Markkula Center for Applied Ethics 2002.

Whittaker, Brain. "Islam and the British Press after 9/11.” Al-bab.com. June 20, 2002. 